\title{
REPERCUSSIONS IN THE LIVING PROCESS OF PEOPLE WITH STOMAS
}

\author{
Marina Soares Motaํ, Giovana Calcagno Gomes², Vilma Madalosso Petuco ${ }^{3}$
}

\begin{abstract}
${ }^{1}$ M.Sc. in Nursing. Nurse at the Health Secretariat in Turuçu. Turuçu, Rio Grande do Sul, Brazil. E-mail: msm.mari.gro@gmail.com 2 Ph.D. in Nursing. Adjunct Professor, Escola de Enfermagem, Universidade Federal do Rio Grande. Rio Grande, Rio Grande do Sul, Brazil. E-mail: giovanacalcagno@furg.br

${ }^{3}$ Ph.D. in Public Health. Full Professor, Instituto de Ciências Biológicas, Universidade de Passo Fundo. Passo Fundo, Rio Grande do Sul, Brazil. E-mail: vmpetuco@upf.br
\end{abstract}

\begin{abstract}
A descriptive study with a qualitative approach that aimed to identify the repercussions of ostomy construction on the living process of people with an ostomy. The study was performed at a Stomatherapy Service from a university hospital in southern Brazil, in the first semester of 2011, with eight patients. Data were collected through semi-structured interviews, and they were analyzed by thematic analysis. We found that the surgery happened to prevent patient deaths. Patients presented themselves as disheartened, angry, sad, having doubts, and they sought to keep the ostomy a secret. They were concerned with the acquisition of resources for self-care. They may present complications and experience embarrassing situations because of the stoma. However, they perceived that they could live with a stoma and regain joy. We concluded that they were able to reframe their lives. We highlight the role of nurses, enabling them for self-care, constituting part of their social support network, helping them to become able to live independently.
\end{abstract}

DESCRIPTORS: Ostomy. Psychosocial impact. Adaptation. Nursing.

\section{REPERCUSSÕES NO PROCESSO DE VIVER DA PESSOA COM ESTOMA}

RESUMO: Estudo descritivo, com abordagem qualitativa, que objetivou conhecer as repercussões da estomização no processo de viver de pessoas com estoma. Este estudo foi realizado em um serviço de estomaterapia de um hospital universitário do Sul do Brasil, no primeiro semestre de 2011, com oito pessoas estomizadas. Os dados foram coletados por meio de entrevistas semiestruturadas e analisados pela análise temática. Evidenciou-se que a cirurgia ocorreu, geralmente, para evitar sua morte. Os pacientes apresentavam-se abatidos, revoltados, tristes e com dúvidas, buscando manter a estomização em segredo. Preocupavam-se com a aquisição dos recursos para seu autocuidado. Podiam apresentar complicações e vivenciar situações constrangedoras relativas ao estoma. No entanto, após adaptados, percebiam que era possível viver com o estoma, recuperando a alegria. Chegou-se à conclusão que eles eram capazes de (re)significar seu viver. Destacou-se o papel da enfermagem, habilitando-os para seu autocuidado, constituindo sua rede de apoio social e auxiliando-os a se tornarem autônomos no seu viver.

DESCRITORES: Estomia. Impacto psicossocial. Adaptação. Enfermagem.

\section{IMPACTOS EN EL PROCESO DE VIVIR CON PERSONAS ESTOMIZADAS}

RESUMEN: Estudio descriptivo con un abordaje cualitativo, que objetivó identificar las repercusiones de la estomización en el proceso de vivir de las personas con estomía. Esto fue realizado en un Servicio de Estoma-Terapia de un hospital universitario en la región Sur del Brasil, en el primer semestre de 2011, con ocho portadores. Los datos fueron recolectados a través de entrevistas semiestructuradas y analizados por el análisis temático. Se encontró que la cirugía se llevó a cabo para evitar su muerte. Los pacientes se presentaron abatidos, enojados, tristes y con dudas. Ellos se preocupaban con la adquisición de recursos para su autocuidado. Presentaron complicaciones y pasaron por situaciones embarazosas debido al estoma. Sin embargo, se dan cuenta que se puede vivir con un estoma y recuperar la alegría. Se deduce que son capaces de replantear sus vidas. Se destaca el papel de la Enfermería que les permite el auto-cuidado, constituyendo parte de su red de apoyo social, ayudándoles a ser capaces de vivir con autonomía.

DESCRIPTORES: Estomía. Impacto psicosocial. Adaptación. Enfermería. 


\section{INTRODUCTION}

An ostomy is a surgical procedure in which there is the externalization of a part of a hollow organ, such as the intestine or bladder, through a hole in the abdomen called a stoma. ${ }^{1}$ It is an aggressive surgical procedure, capable of causing various changes in body physiology, lifestyle, and the physical and psychosocial aspects of a person. ${ }^{2}$ The ostomy surgery imposes a major body change, which can cause changes in the life, self-image and self-esteem of these people. ${ }^{3}$

The person undergoing this type of surgery needs to wear a pouch system on the abdomen to collect stool or urine, thereby becoming dependent on it. This requirement associated with the fear of odor escaping, leaks and noises, in addition to possible restrictions to some life habits, result in concerns and can turn one's life into a painful process. ${ }^{4}$ The person and his/her family must learn the daily management related to the presence of the pouch system and the stoma, and to live with the implications imposed by to this situation.

In today's society, beauty and vigor are overvalued, and deviation from the normal standards can generate a significant sense of rejection. ${ }^{5}$ By undergoing ostomy surgery, a person experiences the deconstruction of her image, her position and her function in the social microspace. She may feel different and present conflicting feelings which, in turn, can inhibit the process of adaptation and acceptance of the new condition of life, demanding a process of adaptation to the new image, identity and self-concept in the search for the existential meaning of her new body. ${ }^{6}$

The difficulties faced by people beginning with the discovery of the cancer diagnosis, stoma construction, and the acceptance of the experienced situation, show that the impact of these factors is indicative of the actual complexity and difficulty of their process of rehabilitation. ${ }^{7}$ In this context, nurses play an important role in this changing process of the person living with a stoma, due to their scientific knowledge and because of their involvement beginning at diagnosis, going through the pre- and post-operative periods, and during follow-up of this person in the outpatient clinic, or even by means of health educational activities and the promotion of self-care. ${ }^{8}$

Therefore, concerns about how to assist these people holistically arise in coping with their daily lives, in light of their different ages, diseases, experiences, subjectivities, feelings and cultures.
Professional practices can promote positive coping strategies for the disease, by broadening the scope of interventions beyond the biological body with a stoma, focusing on the care of the person with a disease. ${ }^{9}$ The amputation of any body segment is traumatic, and can produce radical changes in appearance, by changing one's self-image of his body, and requiring adjustments to the situation by the person with a stoma. In view of the numerous consequences resulting from living with a stoma, this study aimed to identify the repercussions of ostomy in the living process of people with stoma.

\section{METHODS}

This is a descriptive study with a qualitative approach, which studied meanings, motives, aspirations, beliefs, values and attitudes, enabling the researcher to observe the agents in their daily lives, living and socially interacting with them. ${ }^{10} \mathrm{It}$ was performed in a Stoma therapy service (SS) of a university hospital in southern Brazil, in the first semester of 2011.

This service had been open for 24 years, and attended 96 people with stomas and their families during the research period, working in the areas of teaching, research and extension. The objective of the service was teaching self-care and improving the quality of life of people with a stoma. Apart from a reference area in which educational consultations were performed, the person with a stoma received the necessary materials for their care and was invited to participate in group therapies. The group therapies stimulated socializing with others who had undergone or were undergoing similar situations, and made feasible the exchange of experiences and mutual support.

The study subjects were eight people with a stoma, enrolled in this service with temporary or permanent stoma. The inclusion criteria were: being lucid and communicative, and having a stoma for over a year. People with end-stage disease were excluded. During group therapy, patients were invited to participate in the study and those who agreed signed the Terms of Free and Informed Consent. The day and time for data collection were agreed upon.

Data collection was performed by means of a single semi-structured interview with each participant. These were recorded, with an average duration of 60 minutes, and performed in the stoma therapy service office. The interview is a technique that establishes a dialogic relationship with a particular intention, characterized as a promoter of 
opening and deepening of communication. ${ }^{10}$ People were asked about the repercussion of the ostomy surgery in their process of living. Data emerging from the interviews were analyzed by means of the thematic analysis technique ${ }^{10}$ which is divided into three stages: pre-analysis, in which the study data are organized according to the study objectives, performed by grouping statements and constructing registration units; material exploration, in which the data were coded, grouped by similarities and differences, and arranged in categories; and treatment of the results, in which the most significant statements were selected to illustrate the analysis, and the search for authors to support the analysis was performed.

Resolution 196/96 was followed in regard to the ethical aspects of research with human beings. ${ }^{11}$ The research project was approved by the Research Ethics Committee in the Health Area (CEPAS) of Rio Grande Federal University (FURG), under number $79 / 2010$. The anonymity of participants was guaranteed and their statements were identified with the letter " $\mathrm{P}$ ", followed by the interview number.

\section{RESULTS}

Eight people with stomas aged between 42 and 77 years participated in the interviews: four men and four women. All had a temporary or a permanent stoma for more than one year. The types of stomas were: colostomy (four people), ileostomy (one person), and urostomy (three people). They had stomas due to bladder cancer (three), rectal cancer (four), and Crohn's disease (one). Their levels of education ranged from incomplete primary education (four), complete primary education (one), incomplete secondary education (one), to complete secondary education (two).

The thematic data analysis generated two categories: Feelings about the stoma before and after ostomy surgery, and, The difficulties and possibilities of living with a stoma.

\section{Feelings about the stoma before and after ostomy surgery}

Once aware of the diagnosis, people began to experience the impact that surgery would bring to their lives. Although the ostomy represented the difference between living and dying, its presence, associated with the use of the pouch system, was initially so traumatizing that, perceiving themselves with no alternative, even death itself was considered. However, when deciding upon the surgery, they considered their families, spouses, children and life itself, these factors being key determinants for their decision-making. The unconditional support of the family and the health care team for the possibility of solving the serious problem that could lead them to death motivated them to go forward, as expressed in the statements:

If I didn't have the pouch, I wouldn't be here! What to do? To continue living we needed the pouch (P4).

It's a very big impact to realize that you have to undergo surgery or you will die. The idea is complicated, but I had to decide for the pouch. There was no other way (P6).

Suddenly there is a sadness, a sadness. Why did I end up like this? Why stay like this? Then I accept it. Better this than nothing, but it is a mess in the head! That's what happens to us. I know it all comes back again. Why stay like this? It would have been better not to stay like this! (P8).

When I had the surgery in 2003, the first thing I wanted was to die and not have the surgery. I thought my life would end anyway! I will have two pouches and how will my life be? But I had my son, my wife, my home. And I say no! You know what, I won't stay down. Let's get the pouch (P5).

After the surgery, it was found that the person with a recent stoma feels depressed and even angry, may even question the real need for the surgery and medical management. The anger was, at first, a defense mechanism directed at finding the guilty person, who could be, according to what some people with a stoma thought, the healthcare professionals or the person with a stoma herself, due to wrong attitudes or choices that she may have made in the past and that impacted her health:

The doctor performed a surgery which I believe maybe was not even needed! But he said it was necessary. Everyone tells me it wasn't necessary, because I had a tumor only in the bladder and he even took the uterus! All that he messed with didn't have anything, wasn't needed! It makes me sad, anguished and angry! And I wonder, 'why did he do that?' It was just really in the bladder, but he said he needed to do it and did it. Now this is how I am! Without anything! (P8).

We should take care of our health. Because we sometimes do wrong things. We don't take care of our health and that's why we have problems like this that we had (P1).

A significant portion of people had no idea about, and had never even had contact with someone with a stoma before the need for the surgery. Therefore, they did not have a concept of what it 
was to have a stoma. The estrangement from this situation reflected on confrontation of this new life condition. The fear of being different and of the reaction of society has caused many people to keep their ostomy secret, sometimes a secret from themselves, by avoiding looking at their body with a stoma. They could also feel anguished about the unknown and the new image, and needed to learn to take care of the stoma:

When I put on the pouch I had never seen anyone talking about pouches. I thought it didn't exist! I never thought I'd have to deal with it, handle the pouch, this kind of stuff. [...] People don't understand what this is, what the pouch is. It's difficult to talk about, to explain, we don't know how they will react, so I avoid it (P5).

I had never seen anyone like that, with a pouch. So having to take care of it was a little complicated. It's distressing! You have to lock up and hide to take care of yourself. I don't like anyone to see me with this, with this pouch (P3).

Given the irreversibility of the ostomy condition after a while, many were resigned and tried to incorporate the novelty in their lives:

Before, I rejected the pouch. It was strange. I didn't think there could be something like the stoma. Later I didn't. Today, I deal with the pouch more smoothly. In the first three months, I didn't want to look at my pouch. I fought, I fought to try to understand the why of that. Why did this have to happen to me? (P6).

\section{The difficulties and possibilities of living with a stoma}

After the shock from the news, the need and the decision for the ostomy, as well as the initial difficulties of acceptance, a change of focus occurs in the questioning, from "why me" to concerns about dealing with the stoma, and which ways to live with it. There is also the concern about how to acquire the resources that support self-care, because these materials were hard to find in the market, expensive, and of limited distribution by the State Health Secretariat. People were frightened with the possibility of running out of the pouch systems, adhesives, powders and other materials essential for maintaining their quality of life; the lack of these things was a motive for stress, compromising their lives. Thereby, the periodic search for care material made them dependent on the health care service:

I have this concern. Will it be enough? It's that concern of running out of a pouch, not running out of it. I am very well and I have to rush out as I did now. It suddenly struck me that I will not have enough, then I came to get it. That's the biggest concern: the lack, running out of it, of getting there and not having anyone to attend me (P1).

And I was very afraid of running out of pouches. Not today, because I come talk to the nurse and she finds a way. Because at the beginning, $g$ also received themvia Porto Alegre in a clinic. And when I was in the hospital, I thought I would have to buy these pouches and they're very expensive! But every time I went to Porto Alegre at the hospital where I was treated, the nurses gave me two or three of their stock, because they were not allowed to give them. I went to another hospital, my wife also did it, we asked for it and they gave us some. I got by, because I was afraid to run out of it. Not today, because the nurse takes care of everything here, so I don't run out of anything, but at first it was difficult (P4).

It was common for people to have complications after surgery due to their clinical conditions, such as infections and underlying diseases or complications related to the stoma, such as hernias, eviscerations and others, which could be due to failure to comply with the provided instructions:

I had surgical complications. I had generalized infections after the first surgery. I was in ICU several times. It's my body that didn't adapt. It was infected and the proof is here: one year and three months later, I do a daily treatment for the infection. My problem is a sequelae of the surgery, because of a spinal problem. I have a lot of sequelae. My biggest problem is the spine, not the stoma (P6).

The nurse instructed me, but my son went to the beach and asked me to take care of the work, and I ended up having a hernia when unloading a brick truck. I had never done this before and I thought nothing would happen. And now my stomach is full of hernias. It's horrible. People who aren't strong can't see it. One I had after putting my wife in and taking her out of the bed, putting her in the car when she was ill (P4).

In addition to the physical difficulties, the possibility of pouch leakage or the elimination of bowel sounds and gases during social events brought embarrassment, shame and despair, making the impact of surgery even bigger:

I was having dinner at my sister's and I had to run. I had to leave the food and go. Let's go, let's go! Thankfully, my kid has a motorcycle. I called him in a corner, so they wouldn't see me, and asked him to take me away. I didn't say anything! The pouch leaked and I was all evacuated. I was desperate with shame (P8).

I'm tired of leaving home with a pouch, getting to the birthday or elsewhere and having to leave in a hurry because it came off, it leaked. I can't say 'I'll have to 
leave cause I have to change my pouch. I'm so ashamed, ashamed [...]. And I have to leave like this, desperate, without saying why (P1).

The surgery had such overwhelming repercussions that people were sometimes skeptical about the possibility of adapting to the life with a stoma. However, after a period, they became aware of the lack of an alternative, starting to mobilize forces for adaptation and acceptance in the pursuit of quality of life:

I see many people in trouble, depressed, they don't accept it. That thing, you know? The problem is that there's a lot to do. It's either like this or you wouldn't be here! So the solution is to live with it. And try to be happy (P2).

The pouch is there to help me. At first it was difficult. That's all! I don't have anything against it. Rather, if it were not there, then there would be a serious problem (P6).

You're kind of adapted, but the hard way. I don't know whether one day I will actually adapt, but for now, that's it. I'm trying to (P3).

Those who realized that the ostomy is a possibility to have a better life, that it was possible to recover the joy of living and give a sense of normalcy to their lives started to feel good and to seek to live with quality:

After I had this stoma, I feel fine. I'm willing to eat, to work, to walk. At first I was worried because of these pouches, because I have to stick with it until the end of life. But not now, I feel good. Before I was very angry. I felt bad. Gradually I got better. I started sleeping well, eating well, eating it all. I'm happy because I lead a good life (P7).

I improved a lot. I don't feel pain. I adapted well. Because I faced it as a natural matter. I decided to live my life quietly. Practically little has changed in my life (P5).

However, it was found that, despite understanding that the surgery made the continuity of life possible and there was the need to adapt to this new way of living, the person hoped that one day, her stoma would be reversed. Perhaps this fact revealed that adaptation is relative to something different from what is considered "normal", i.e., the exit of stools out of another body site, occasioned by the pressing need for preservation of life. This apparent temporary acceptance has been fueled by hopes of one day having the possibility to rebuild the intestinal transit again, regardless of the stoma being temporary or permanent:

[...] I adapted! Like this, the way I told you. If I could take it off, go back, I would. I was about to have the reversal surgery, but it's kind of complicated. If you have it and it doesn't work out, it's the only chance you have. Then you stay put. It's awful. It's very hard. You worry a lot because there can't be a mistake (P8).

Of course I want to take the pouch off and all. But if suddenly it fails and I have to stay like this, I know it will still be a gain. I'm adapted, but I'm very eager to take it off (P5).

Even those people who had had a permanent stoma for some time, without the slightest possibility of reversion, reported failure adapting to this condition:

\section{I did not adapt well. No way! Even after years (P3).}

There was no way I'd tell people that I use it. I can't accept it (P1).

Sometimes I can't believe I'm wearing this pouch. I wasn't ready for it. I don't feel adapted. Sometimes I ask myself, 'Why am I going through all this? (P8).

\section{DISCUSSION}

The ostomy surgery is performed in order to maintain the intestinal or urinary elimination function necessary for life, but it generates several changes in the body physiology, lifestyle, and the physical and psychosocial aspects of a person. ${ }^{12}$ Thus, the category "Feelings about the stoma before and after ostomy surgery" demonstrated that, without an alternative before surgery, the candidate was left with the only option of accepting it, although it represented the difference between life and death. The lack of experience with a stoma can lead to an emotional breakdown after surgery, causing the people with a stoma to often make references to death. Others also showed insecurity and uncertainty about their future with the stoma. ${ }^{13}$

Beyond the matter of survival, the category pointed to the family as one of the reasons for the decision to have surgery. Thinking about the importance for oneself and the care needs of the family made the stoma candidate mobilize strengths towards acceptance of surgery. The family played an important role in supporting the person with a stoma, mobilizing a new identity, the resumption of self-esteem and social reintegration, which could have been affected with the ostomy..$^{14}$ Social isolation is viewed as a result of the lack of emotional and social support, particularly from the family. ${ }^{15}$ The health condition of the person with a stoma was profoundly influenced by psychosocial issues. Receiving emotional support was crucial to improving their quality of life, ${ }^{16}$ with the family having a decisive role. 
In this category, it was found that, even after submitting to the ostomy surgery, people with a stoma were depressed and even angry with the ostomy in the first months. Not uncommonly, the anger reverberated in the search for answers, and these people started questioning the real need for surgery, looking for a culprit for their condition of having a stoma. However, it is necessary to respect the injuries, resentments, anger and losses in order to contribute to the acceptance of the new life condition, which is revealed after surgery. Usually the questioning and anger are a necessary step, given the impact of the stoma on their lives, which culminates in acceptance and mental adaptation to changes after a period of recovery and learning about the physical changes. ${ }^{14}$

Within this category, there was a significant portion of people undergoing ostomy surgery who had never seen a stoma nor did they know that this surgical procedure existed. Therefore, the strangeness of the stoma image and dynamics of elimination in their bodies could have repercussions on peoples' lives, now with a stoma, and they started to feel different from the rest of society. Thus, they sought to keep their stomas and the pouch system hidden from the society, even avoiding looking at their own bodies. A study shows that living with a stoma is difficult, with feelings of uncertainty about the present and the future, and their own life prospects being common. After surgery, living represents vicissitudes associated with physical, psychological and social dimensions, and requires continuous attention. ${ }^{3,17}$

Challenges arise from the discovery of the diagnosis until adaptation to new living conditions after discharge and rehabilitation can be a difficult process. ${ }^{7}$ The category also showed that becoming a person with a stoma brought the need to develop skills to maintain both the stoma and the pouch system. The person can be distressed by the need to care for the body in this new conformation. The pre- and post-operative educational interventions performed by nurses significantly influenced the adaptation to the new life situation, facilitating selfcare and social(re)integration. ${ }^{15}$

Upon being notified of the diagnosis and the need to undergo ostomy surgery, many experienced feelings of emotional clutter and changes in their life trajectory, a fact evidenced in the category. The difficulties and possibilities of living with a stoma. It was found, however, that time is an important ally for the person to adapt to this new life situation, ${ }^{18}$ because he gradually begins to change his attitude towards the ostomy, movin from the question "why me?" to a positive attitude regarding the development of skills that at least enable living with the stoma.

People with a stoma have moderate levels of acceptance, the more recent the disease and ostomy, the lower the levels of acceptance of the life condition. ${ }^{19}$ In addition to the subjective issues regarding adaptation and acceptance, the data show that the material matters are to be considered, as the person with a stoma needs the pouch system and devices for self-care with the stoma and the peristomal skin, which could impact her financial life. After the ostomy, the person is considered physically disabled ${ }^{20}$ and can integrate into the Assistance Program for People with Stomas. ${ }^{1}$ This program is maintained by the public service and offers free devices monthly for people with stomas to care for their skin and the stoma.

However, people with a stoma, and/or their family caregivers, need to commute every month to the service to obtain the devices, thereby becoming dependent on it for their care, which was noted as one of the difficulties of living with a stoma. Their existence now becomes represented by the materiality of the stoma in their bodies, dependent on the pouch system and other devices, without control over the sphincter. ${ }^{21}$

Another difficulty pointed out in the category was the fact the ostomy surgery can cause complications such as prolapses and hernias, among others, which can be prevented by adequate lifestyle, by following preventive instructions from health care professionals. In this sense, the nursing consultation serves as a key moment, in addition to supporting the promotion of activities and direct follow-up of the person, thereby preventing stoma-related complications, and helping deal with the difficulties caused by changes after the ostomy. ${ }^{22}$

In the process of adaptation, there may be moments of progress and setbacks, resulting in an evolution in coping with difficult situations. The daily life routine, with return to society, can represent moments of significantly expressed difficulties which can be complex, such as shame, fear, insecurity and especially embarrassment, ${ }^{14}$ with repercussions that may at first seem negative. However, during these moments one can establish coping strategies, strengthening the person with a stoma.

The ostomy surgery changes the life of the person and her family, reflecting on their quality of life. However, as the person with a stoma returns 
to the activities performed prior to the surgery, and establishes a better relationship with herself and her permanent or temporary stoma situation, she starts to live better, thereby seeing the possibilities of living with a stoma. Factors such as surgical complications, comorbidities, sexual function, and even the ability to get care resources such as the pouch system impact on quality of life of people with a stoma. Nursing interventions can mitigate the negative effects, contributing to a better quality of life. ${ }^{23}$

Even when the person with a stoma had a good adaptation and high quality of life, the surgical reversal, which is the reconstruction of the intestinal tract, is desired and expected, which was evidenced in the statements of some of the study subjects. People with a temporary stoma, i.e. those with a possibility of reversing the ostomy, undergo an adaptation process similar to that of people with a permanent stoma. However, the hope of reversal persists, causing anxiety that may hinder the development of skills and competencies for self-care. ${ }^{6}$ There are also people with a stoma who do not feel adapted and are unale to even accept this situation, remaining sad and unbelieving about this life condition. However, every person has his uniqueness, his way of coping and adapting to the new condition, and can live with suffering, pain, uncertainty, myths and fears. ${ }^{14}$

Nursing, within this reality, has the role of facilitator of the care processes. The nurse occupies a unique position among the professionals caring for people with a stoma, being extensively involved with the development of self-care. ${ }^{8}$ Thus, the nurse emerges as a transforming health agent by acting as an educator of people with a stoma and their families, thereby using educational technologies to help facilitate the understanding of knowledge, making self-care something that can be attained. ${ }^{24}$

\section{FINAL REMARKS}

The objective of knowing the repercussions of the ostomy in the living process of people with a stoma was achieved. Ostomy was an adverse and complex event in a person's life, who suffers an important modification of her existence and her body, often seeking an attempt to approach the person before surgery, hiding her new life condition with a stoma, not even allowing herself to look at her body with a stoma.

The ostomy was concluded to cause a profound repercussion on the lives of people with a stoma. The construction of a social support net- work in which health care professionals and family caregivers must unite to help these people in their adaptation is necessary. Noteworthy is the nurse's role in self-care education, providing instruction and support, so they can care for their stoma and perform the periodic exchanges of their pouch systems independently.

Assistance is necessary in coping with the difficulties experienced in their daily lives as a means of subsidizing and empowerment, contemplating the psychological, social and religious aspects of care, in addition to the technical ones. Family caregivers of people with a stoma must also be cared for because they are the ones living with them daily, their main source of care and support, undergoing the impact of ostomy with them. Identifying the repercussions of ostomy to people with a stoma and sensitizing oneself to the way they deal with the new reality become indispensable elements for the construction of an effective care plan, and the implementation of therapeutic strategies to assist in their adaptation. Only then will these people will be able to find new meaning in their lives. Further studies are needed in order to produce knowledge on adaptive strategies implemented by people with a stoma to qualify their living and help health care professionals qualify themselves to care for them.

\section{REFERENCES}

1. Ministério da Saúde (BR). Secretaria de Atenção à Saúde. Portaria SAS/MS no 400 de 16 de novembro de 2009 [online]. Brasília (DF): Ministério da Saúde. [acesso 2014 Dez 19] Disponível em: http:// bvsms.saude.gov.br/bvs/saudelegis/sas/2009/ prt0400_16_11_2009.html

2. Coelho AR, Santos FS, Dal Poggetto MT. Stomas changing lives: facing the illness to survive [online]. 2013 [acesso 2014 Dez 19]; 17(2):258-77. Disponível em: http://www.reme.org.br/artigo/detalhes/649.

3. Kimura CA, Kamada I, Guilhem D, Monteiro PS. Quality of life analysis in ostomized colorectal cancer patients. J Coloproctol [online]. 2013 [acesso 2014 Dez 19]; 33(4):216-21. Disponível em: http:// www.sciencedirect.com/science/article/pii/ S2237936313000622

4. Espadinha AMN, Da Silva MMDECVZN. O colostomizado e a tomada de decisão sobre a adesão à irrigação. Rev Enferm Ref [online]. 2011 [acesso 2014 Dez 19]; 3(4):89-96. Disponível em: http:// www.scielo.oces.mctes.pt/scielo.php? pid $=$ S087402832011000200009\&script=sci_arttext

5. Cassero PAS, Aguiar JE. Percepções emocionais influenciadas por uma ostomia. Rev Saúde Pesq [online]. 2009 [acesso 2014 Dez 19]; 2(2):23-7. 
Disponível em: http://periodicos.unicesumar.edu. $\mathrm{br} /$ index.php/saudpesq/article/view/1058/780

6. Souza PCM, Costa VRM, Maruyama SAT, Costa ALRC, Rodrigues AEC, Navarro JP. As repercussões de viver com uma colostomia temporária nos corpos: individual, social e político. Rev Eletr Enferm [online]. 2011 [acesso 2014 Dez 19]; 13(1):50-9. Disponível em: http://www.fen.ufg.br/revista/v13/n1/pdf/ v13n1a06.pdf

7. Gemmill R, Kravits K, Ortiz M, Anderson C, Lai L, Grant M. What do surgical oncology staff nurses know about colorectal cancer ostomy care? J Contin Educ Nurs. 2011; 42(2):81-8.

8. Moraes JT, Sousa LA, Carmo WJ. Análise do autocuidado das pessoas estomizadas em um município do centrooeste de Minas Gerais. Rev Enferm Cent O Min [online]. 2012 [acesso $2014 \mathrm{Dez}$ 19]; 2(3):337-46. Disponível em: http://www.seer. ufsj.edu.br/index.php/recom/article/view/224/348

9. Mattos M, Maruyama SAT. A experiência de uma pessoa com doença renal crônica em hemodiálise. Rev Gaúcha Enferm [online]. 2010 [acesso 2014 Dez 19]; 31(3):428-34. Disponível em: http:/ / www.scielo.br/scielo.php?pid=S1983$14472010000300004 \&$ script $=$ sci_arttext

10. Minayo MC. O desafio do conhecimento: pesquisa qualitativa em saúde. $11^{\text {a }}$ ed. São Paulo/Rio de Janeiro: HUCITEC/ABRASCO; 2008.

11. Ministério da Saúde (BR). Conselho Nacional de Saúde. Resolução no 196, de 10 de outubro de 1996: diretrizes e normas regulamentadoras de pesquisas envolvendo seres humanos. Brasília (DF): CNS; 1996.

12. Santana JCB, Souza AB, Dutra BS. Perceptions of a group of nurses on the process of caring for patients with permanent colostomy. Rev Enferm UFPE On Line [online]. 2011 [acesso 2014 Dez 19]; 5(7):17105. Disponível em: http://www.revista.ufpe.br/ revistaenfermagem/index.php/revista/article/ viewArticle/1722. Portuguese.

13. Brum CN, Sodré BS, Prevedello PV, Quinhones SWM. O processo de viver dos pacientes adultos com ostomia permanente: uma revisão de literatura. Rev Pesq Cuid Fundam [Internet]. 2010 [acesso 2014 Dez 19]; 2(4):1253-63. Disponível em: http://www.seer. unirio.br/index.php/cuidadofundamental/article/ viewFile/660/pdf_83

14. CetolinSF, BeltrameV, CetolinSK, Presta AA. Dinâmica sócio-familiar com pacientes portadores de ostomia intestinal definitiva. ABCD Arq Bras Ci Dig [online]. 2013 [acesso 2014 Dez 19]; 26(3):170-2. Disponível em: http://www.scielo.br/scielo.php?script=sci arttext\&pid=S0102-67202013000300003\&lng=en

15. Nichol S, Thom R. Social connectivity in those 24

Correspondence: Marina Soares Mota.

399 Vereador Elberto Madruga St

96075-220 - Cruzeiro, Pelotas, RS, Brazil

E-mail: msm.mari.gro@gmail.com months or less postsurgery. J WOCN. 2011; 38(1):63-8.

16. Poletto D, Silva DMGV. Living with intestinal stoma: the construction of autonomy for care. Rev Latino-Am Enfermagem [online]. 2013[acesso 2014 Dez 19]; 21(2): Disponível em: http://www.scielo.br/pdf/rlae/ v21n2/pt_0104-1169-rlae-21-02-0531.pdf

17. Sales CA, Violin MR, Waidman MAP, Marcon SS, Silva MAP. Emotions of people living with ostomies: existential comprehension. Rev Esc Enferm USP [online]. 2010 [acesso $2014 \mathrm{Dez} 19] ;$ 44(1):221-7. Disponível em: http://www.scielo.br/scielo. php? pid=S0080-62342010000100031\&script $=$ sci $_{-}$ arttext\&tlng=es

18. Santana JCB, Dutra BS, Tameirão MA, Silva PF, Moura IC, Campos ACV. O significado de ser colostomizado e participar de um programa de atendimento ao ostomizado. Cogitare Enferm [online]. 2010 [acesso 2014 dez 19]; 15(4):631-8. Disponível em: http:// ojs.c3sl.ufpr.br/ojs2/index.php/cogitare/article/ view/20358/13519

19. Chao HL, Tsai TY, Livneh H, Lee HC, Hsieh PC. Patients with colorectal cancer: relationship between demographic and disease characteristics and acceptance of disability. J Adv Nurs. 2010; 66(10):2278-86.

20. Brasil. Decreto-lei n. 5.296 de 2 de dezembro de 2004. Regulamenta as Leis nos 10.048 , de 8 de novembro de 2000, que dá prioridade de atendimento às pessoas que especifica, e 10.098, de 19 de dezembro de 2000, que estabelece normas gerais e critérios básicos para a promoção da acessibilidade das pessoas portadoras de deficiência ou com mobilidade reduzida, e dá outras providências. Brasília (DF): DOU; 2004.

21. Souza JL, Gomes GC, Barros EJL. O cuidado à pessoa portadora de estomia: o papel do familiar cuidador. Rev Enferm UERJ [online]. 2009 [acesso 2014 Dez 19]; 17(4):550-5. Disponível em: http:/ / www.facenf.uerj. br/v17n4/v17n4a17.pdf

22. Nascimento CMS, Trindade GLB, Luz MHBA, Santiago RF. Vivência do paciente estomizado: uma contribuição para a assistência de enfermagem. Texto Contexto Enferm [online]. 2011 [acesso 2014 Dez 19]; 20(3):557-64. Disponível em: http:/ /www.scielo.br/ pdf/tce/v20n3/18.pdf

23. Caetano CM, Beuter M, Jacobi CS, Mistura C, Rosa BVC, Seiffert MA. O cuidado à saúde de indivíduos com estomias. Rev Bras Ciênc Saúde [online]. 2014[acesso 2014 dez 19]; 12(39):59-65. Disponível em: http://seer.uscs.edu.br/index.php/revista_ciencias_ saude/article/view/2100/1487

24. Barros EJL, Santos SSC, Gomes GC, Erdmann AL. Gerontotecnologia educativa voltada ao idoso estomizado à luz da complexidade. Rev Gaúcha Enferm. 2012; 33(2):95-101.

Received: July 10, 2014 Approved: April 07, 2015 